He received the Harrison Memorial Prize (awarded by the Chemical Society, the Institute of Chemistry, the Society of Chemical Industry and the Pharma. ceutical Society) and the Meldola Medal (awarded by the Institute of Chemistry), both of which are given for research carried out by a worker less than thirty years of age. His main researches have been carried out in the field of organic chemistry, but have not been entirely confined to this field. He has published seventy-four original papers in the Journal of the Chemical Society, of which sixty-five are essentially on organic chemical topics. He is joint author with Prof. J. F. Thorpe of the seventh edition of Cain and Thorpe's "Synthetic Dyestuffs", and has written a number of articles for the "Dictionary of Applied Chemistry".

\section{Mr. A. J. H. Edwards}

Mr. A. J. H. EDwards has been appointed director of the Scottish National Museum of Antiquities in succession to Dr. J. G. Callendar, who died on March 19. Mr. Edwards is the son of the late Capt. John Edwards of Dundee, one of the last of the well-known arctic whalers. He was educated at Robert Gordon's College, Aberdeen, and joined the staff of the Natural History Department of the Royal Scottish Museum in 1906. In 1912 he was appointed assistant keeper of the National Museum of Antiquities, and in 1913 went to Germany to study the preservation of antiquities with Prof. Rathgon, principal chemist to the German Government Museums. During the Great War he served in Malta, Salonika, Egypt and Palestine in the ranks and as an officer on the General List. He returned to the Museum of Antiquities in 1919 and also continued studies abroad. Mr. Edwards has visited the large museums in Norway, Sweden, Denmark and France and has contributed from time to time articles on archæological subjects which have been published in the Proceedings of the Society of Antiquaries of Scotland and other journals.

\section{The Herbert Jackson Prize}

THe London Midland and Scottish Railway announces that the first award of the Herbert Jackson Medal and Prize has been made to Mr. A. S. Davison, of the Crewe Chemical Laboratory, for a paper on the "Chemical and Biological Examination of Water Supplies". This medal has been struck by the Company in memory of the late Sir Herbert Jackson, and is to be awarded annually to a member of the Company's research staff for the best written account of an investigation carried out in the Company's laboratories during the year. Sir Herbert Jackson was an original member of the L.M.S. Advisory Committee on Scientific Research, on which he served from 1930 until his untimely death in 1936. $\mathrm{He}$ played an invaluable part in guiding the earlier work of the Committee, and above all, in encouraging the many members of the Company's scientific staff with whom he came into contact, and the directors felt that it would be appropriate to perpetuate his memory by the foundation of an annual prize for the encouragement of scientific research.

\section{Sunspot, Magnetic Storm and Aurora on May I I}

ON May 10.4 a large sunspot, crossing the sun's disk between May 4 and 17, reached the central meridian. The sunspot had originated on the sun's invisible hemisphere, and it seemed of possible significance that the longitude of the spot, $189^{\circ}$, differed little more than $10^{\circ}$ from that of the large and spectroscopically active spot associated with the great magnetic storm of April 16 (NATURE, April 23, p. 721). On May 11 at $15^{\mathrm{h}} 52^{\mathrm{m}}$ U.T. a magnetic disturbance began, and this developed within a few hours into a "great" magnetic storm which, reaching a maximum towards $0^{\mathrm{h}}$ (May 12), was accompanied by a display of the aurora borealis. At Greenwich the aurora was first seen by chance at $23^{\mathrm{h}} 48^{\mathrm{m}}$ U.T. by two of the astronomical observers, though from other reports it must have appeared some minutes before this time. The aurora, which was bright and of a deepish red colour, was described as having the form of a fan-shaped bundle of rays the apex of which extended to about $10^{\circ}$ south of the zenith; at $0^{\mathrm{h}} 10^{\mathrm{m}}$ only faint streamers were visible. Since there was bright moonlight at the time, this aurora must have been intrinsically a very bright one, and doubtless other features would have been seen had the sky been dark. The records from the Greenwich magnetic station at Abinger, kindly communieated by the Astronomer Royal, give the following (provisional) ranges: in Declination, $80^{\prime}$; in Horizontal Force, $960 \gamma$; and in Vertical Force, $420 \gamma$. There was considerable ionospheric disturbance affecting long-distance short-wave radio transmission during the period of magnetic disturbance.

THIs magnetic storm, as pointed out by Greenwich, adds yet another member to a recognizable group of storms indicating a "magnetically" active region of the sun, extending over about $120^{\circ}$ of longitude, which has been in operation since the beginning of 1937. If for each of the thirty-five magnetic storms recorded since then at Abinger, the longitude of the sun's central meridian at the time of the respective commencements be tabulated, it is found that in twenty-four cases (nearly 70 per cent) the solar longitudes lie between $60^{\circ}$ and $180^{\circ}$; the remaining eleven storms are spread over the remaining $240^{\circ}$ of longitude. It may also be noted that the seven "great" storms occurring during the last fifteen months correspond to solar longitudes $120^{\circ}$ to $180^{\circ}$. Paradoxical though it may appear from the wellestablished statistical relationship between large sunspots and large magnetic storms, the distribution in longitude of large sunspots (in area greater than or equal to 500 millionths of the sun's hemisphere) over the epoch January 1937-May 1938 does not, however, favour these particular longitudes, but is more or less a random distribution. It is, of course, impossible to say how much longer this "magnetic. ally" active region of the sun will continue to be associated with terrestrial magnetic storms, but the return of these longitudes to the sun's central meridian centred about June 8 will be observed with interest. 